\title{
FORMULATION AND EVALUATION OF HERBAL ANTIBACTERIAL GEL CONTAINING ETHANOLIC EXTRACT OF MIKANIA MICRANTHA KUNTH LEAVES
}

\author{
NINA IRMAYANTI HARAHAP ${ }^{1 *}$, MARLINE NAINGGOLAN ${ }^{2}$, URIP HARAHAP $^{2}$ \\ ${ }^{1}$ Department of Biological Pharmacy, Faculty of Pharmacy, University of Sumatera Utara, Medan, Indonesia. ${ }^{2}$ Department of Pharmacology, \\ Faculty of Pharmacy, University of Sumatera Utara, Medan, Indonesia. Email: ninaharahap17@gmail.com
}

Received: 28 August 2017, Revised and Accepted: 14 December 2017

\section{ABSTRACT}

Objective: This study was to check the effectiveness of Mikania micrantha Kunth against the microbial species of Staphylococcus epidermis, to observe the zone of inhibition, and to develop a topical gel formulation of M. micrantha Kunth for the treatment of acne vulgaris.

Methods: The extraction was done by maceration method and continues with phytochemical screening and herbal gel formulation (four formulas) using hydroxylpropyl methylcellulose as a base. The gel was evaluated for the physical appearance, $\mathrm{pH}$, homogeneity, and antibacterial.

Result: The ethanolic extract of M. micrantha Kunth had a high value of alkaloids, flavonoids, and tannins. All of the formula (F1-F4) showed a good result in physicochemical and antibacterial evaluation.

Conclusion: M. micrantha Kunth can be used to treat the skin diseases, especially acne vulgaris problem.

Keywords: Acne, Extract, Gel, Herbal, Mikania micrantha Kunth, Staphylococcus epidermis.

(c) 2018 The Authors. Published by Innovare Academic Sciences Pvt Ltd. This is an open access article under the CC BY license (http://creativecommons. org/licenses/by/4. 0/) DOI: http://dx.doi.org/10.22159/ajpcr.2018.v11i3.22211

\section{INTRODUCTION}

Acne vulgaris is one of the most common diseases of the skin with a prevalence of $70-85 \%$ in adolescents, and in cases of extreme disfiguration, sometimes have severe consequences for the personality development of young people, which is associated with a relatively high prevalence of depression and suicide [1,2]. Many patients fail to improve with the current anti-acne therapy due to the cost of therapy, adverse effects leading to non-compliance, or lack of the therapeutic benefits of current antibiotics, while clinically useful antibiotics are facing major setbacks, including a narrow spectrum of activity, neurotoxicity, nephrotoxicity, ototoxicity, severe damage of liver, bone marrow depression, and sound problem of resistance [3-6].

Consequently, attention has been devoted to safe, new, and/or alternative antimicrobial materials in the field of antimicrobial therapy [7]. Therefore, studies and measures must be taken to reduce these problems such as advocated some strategies include knowing the use of antibiotics, studying the genetic mechanisms of resistance, formulating the new effective solution, and developing new antimicrobials from different sources such as natural product [8]. The most effective drug delivery system for skin diseases is using the topical way. A topical drug delivery system designed to deliver a variety of drugs to the body through diffusion across the skin layers while the effectiveness of topical application mainly depends on its rate and extent of drug release from the base [9].

Formulation for enhancing the effectiveness of extract (Mikania micrantha Kurth plant) on human skin using HPMC as gel's base. HPMC is a semisynthetic, inert, viscoelastic polymer which used in many topical formulations, especially in gel [10]. The gel is a topical preparation that is easily applied to the skin and has an attractive physical appearance compared to other topical preparations. Its use is preferred because these supplies gel contains water that is cooling, smoothing, moisturizing, easy usage, and easily penetrate into the skin, thus giving a faster healing effect in accordance with the base used $[11,12]$.
One of the well-known medicinal plants used in the South Tapanuli district in Sumatera Island, Indonesia, M. micrantha Kunth (EnglishAmerican rope; China-Chinese creeper; and Indonesia-Sambung rambut/ Siropaspara) [13]. South Tapanuli societies have been believed that sambung rambut leaves can be used as an antimicrobial and skin diseases treatment. Therefore, the present study was conducted to evaluate the antibacterial gel activity of $M$. micrantha Kunth leaves extract using the standard antibacterial methods and to formulate topical gel, while the gel was evaluated for physical appearance, $\mathrm{pH}$, and homogeneity.

\section{METHODS}

\section{Collection of plant material}

The leaves of $M$. micrantha Kunth were obtained from the Sigma Dalan village in Padang Bolak (North Sumatera Province-Indonesia). The authenticated was done by the Indonesian Institute of Sciences, Research Center for Biology.

Preparation of $M$. micrantha Kunth leaves ethanolic extract and gel Extraction was done by a stratified maceration method using $1000 \mathrm{mg}$ of powdered $M$. micrantha Kunth leaves which were macerated in ethanol solvent for 3 days, then filtered, do it continuously until the filtrate obtained is clear and colorless [14]. For topical gel application (Table 1), gel of ethanolic extract was prepared using simple gel base in four concentrations, i.e., $10 \%, 12.5 \%, 15 \%$, and $17.5 \%$.

\section{Phytochemical screening of ethanolic extract}

Phytochemical screening carried out on ethanolic includes examining the chemical secondary metabolites of alkaloids, flavonoids, glycosides, tannins, triterpenoids, and steroids [14-16].

\section{Evaluation of gel}

Physical appearance

The physical appearance of the gel was checked visually such as the color, odor, consistency, and greasiness. The observation was conducted for 12 days. 
pH determination

The $\mathrm{pH}$ of gel was determined using a $\mathrm{pH}$ meter.

\section{Homogeneity test}

Observation of its homogeneity by applying a certain number of gels on a piece of transparent glass and covered with glass object, then observed. The gel must demonstrate a homogenous and there was no visible presence of grain.

\section{Antibacterial evaluation}

The bacterial strain used in the study is Staphylococcus epidermis (ATC 12228 ) which is the main factor of acne vulgaris. The antibacterial gel will be tested using the agar diffusion test. The method of antibacterial was assayed using the standard procedure assay. Antibacterial activity was recorded by measurement of zone of inhibition around each disc in the plate using zone reader. Each assay was performed using triplicate and mean, all the three experiments were taken [10,17]. The standard antibacterial to compare is Bioplacenton ${ }^{\circledR}$.

Table 1: Formula data for $100 \mathrm{~g}$ M. micrantha Kunth gel formulation

\begin{tabular}{lllll}
\hline Ingredients & \multicolumn{2}{l}{ Quantity } & & \\
\cline { 2 - 5 } & F1 & F2 & F3 & F4 \\
\hline M. micrantha Kunth (\%) & 10 & 12.50 & 15 & 17.50 \\
HPMC (\%) & 3.50 & & & \\
Propylene glycol (\%) & 15 & & & \\
Methylparaben (\%) & 0.20 & & & \\
Ethylparaben (\%) & 0.05 & & & \\
Distilled water & q.s & & \\
\hline HPMC. Hydroxylpropyl methylcellulo
\end{tabular}

HPMC: Hydroxylpropyl methylcellulose, M. micrantha: Mikania micrantha

Table 2: Phytochemical screening result of M. micrantha Kunth ethanolic extract

\begin{tabular}{ll}
\hline Screening & Ethanol extract \\
\hline Alkaloids & Positive \\
Flavonoids & Positive \\
Glycosides & Negative \\
Tannins & Positive \\
Triterpenoid & Negative \\
Steroids & Negative \\
Saponins & Negative \\
\hline
\end{tabular}

\section{RESULTS}

\section{Phytochemical screening}

Screening results of various extract of M. micrantha Kunth leaf extract are presented in Table 2 .

\section{Evaluation of gel}

The result of physical appearance, $\mathrm{pH}$, and homogeneity of $M$. micrantha Kunth gel are summarized in Table 3.

\section{Antibacterial evaluation}

Antibacterial testing was done by agar diffusion method. The zone of inhibition was summarized in Table 4 and Fig. 1.

\section{DISCUSSION}

The phytochemical screening of crude ethanolic extract of powdered M. micrantha Kunth leaves recorded very high values for alkaloids, flavonoids, and tannins compounds. The high values that recorded for the plant extract showed that powdered M. micrantha Kunth maybe a good source of antimicrobial, especially as antibacterial agent. Four different gel base (F1-F4) were formulated using a different concentration of $M$. micrantha Kunth. From the evaluation of M. micrantha Kunth gel showed that all of the formulas had similar physical appearance, $\mathrm{pH}$ and homogeneity.

The antibacterial testing method used in this research was the agar diffusion method (Kirby-Bauer) that is by measuring the inhibition zone diameter of bacteria around the paper disc. Inhibitory zone diameter increases with increasing concentration of extract. It can be showed from the zone of inhibition from four formulas in which the F4 is higher, followed by F3, F2, and F1. From the antibacterial assay, the data from the zone of inhibition showed the ethanolic extract of M. micrantha Kunth significant activity against $S$. epidermis (ATCC 12228).

Medicinal plants are an important source for the development of new chemotherapeutic agents [18]. Flavonoid and tannin compounds are a class of phenol compounds [19,20], which are known to have antimicrobial activity that is bactericidal but not sporicidal. Phenol compounds act as denaturing agent to membrane plasma of microorganism, which leads to leakage and death of cells [21]. The activity of an antibacterial agent in inhibiting growth or killing bacteria depends on the concentration and type of antimicrobial material. The higher the concentration of the extract, the larger the diameter of the inhibition area is because the more active substances contained in the extract.

Table 3: Summary of physical appearance, pH, and homogeneity of M. micrantha Kunth gel

\begin{tabular}{|c|c|c|c|c|c|c|c|c|}
\hline \multirow[t]{2}{*}{ Parameters } & \multicolumn{4}{|l|}{ Day 0} & \multicolumn{4}{|l|}{ Day 4} \\
\hline & F1 & F2 & F3 & F4 & F1 & F2 & F3 & F4 \\
\hline Color & Brown & Brown & Brown & Brown & Brown & Brown & Brown & Brown \\
\hline Odor & Stable & Stable & Stable & Stable & Stable & Stable & Stable & Stable \\
\hline Greasiness & Non-greasy & Non-greasy & Non-greasy & Non-greasy & Non-greasy & Non-greasy & Non-greasy & Non-greasy \\
\hline Consistency & Good & Good & Good & Good & Good & Good & Good & Good \\
\hline $\mathrm{pH}$ & 6.2 & 6.2 & 6.2 & 6.2 & 6.2 & 6.2 & 6.2 & 5.9 \\
\hline \multirow[t]{2}{*}{ Parameters } & \multicolumn{4}{|l|}{ Day 8} & \multicolumn{4}{|l|}{ Day 12} \\
\hline & F1 & F2 & F3 & F4 & F1 & F2 & F3 & F4 \\
\hline Color & Brown & Brown & Brown & Brown & Brown & Brown & Brown & Brown \\
\hline Odor & Stable & Stable & Stable & Stable & Stable & Stable & Stable & Stable \\
\hline Greasiness & Non-greasy & Non-greasy & Non-greasy & Non-greasy & Non-greasy & Non-greasy & Non-greasy & Non-greasy \\
\hline Consistency & Good & Good & Good & Good & Good & Good & Good & Good \\
\hline $\mathrm{pH}$ & 6.2 & 6.2 & 6.2 & 5.8 & 6.2 & 6.2 & 6.2 & 5.6 \\
\hline
\end{tabular}

M. micrantha: Mikania micrantha 
Table 4: Antibacterial activity of $M$. micrantha Kunth gel formulation

\begin{tabular}{lll}
\hline Name of formula & Culture & Zone of Inhibition in $\mathbf{~ m} *$ \\
\hline F1 & S. epidermis & $13.07 \pm 0.2$ \\
F2 & & $14.10 \pm 0.13$ \\
F3 & & $15.83 \pm 0.4$ \\
F4 & & $16.69 \pm 0.1$ \\
Bioplacenton® & S. epidermis & $26.99 \pm 0.15$ \\
\hline
\end{tabular}

*Values are given as mean \pm SEM for triple measurement. SEM: Standard error of the mean, M. micrantha: Mikania micrantha, S. epidermis: Staphylococcus epidermis

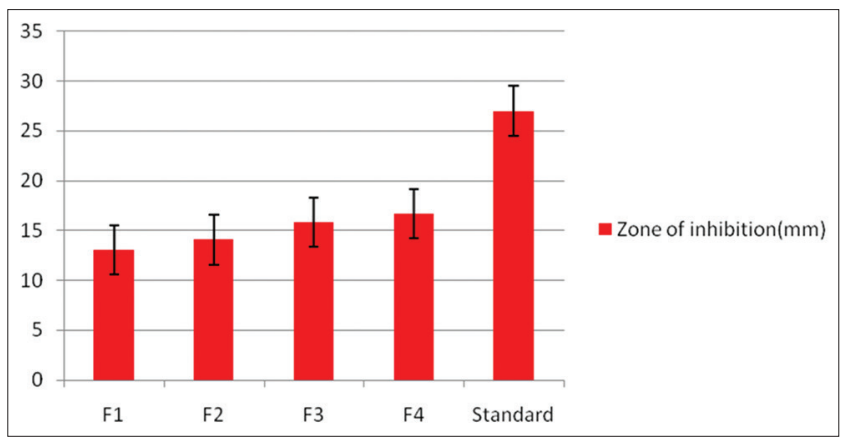

Fig. 1: Graphic of antibacterial effect from Mikania micrantha Kunth gel

\section{CONCLUSIONS}

M. micrantha Kunth extract showed a good potential antibacterial agent for S. epidermis. The gel of M. micrantha Kunth also showed good physicochemical properties which can be concluded that this herbal gel made from $M$. micrantha Kunth can be used to treat the skin diseases, especially acne vulgaris.

\section{ACKNOWLEDGMENTS}

The author would like to thank the Faculty of Pharmacy and Iksen, S.Farm., M.Si., for the support and providing the research work and publication.

\section{REFERENCES}

1. Bhalani U, Shah K. Preparation and evaluation of topical gel of Nigella sativa (Kalonji). Int J Res Dev Pharm Life Sci 2015;4:1669-72.
2. Thiboutot DM, Starus JS. Diseases of the Sebaceous Glands. $6^{\text {th }}$ ed. New York: The McGrawhillcom; 2003.

3. Stathakis V, Kilkenny M, Marks R. Descriptive epidemiology of acne vulgaris in the community. Australas J Dermatol 1997;38:115-23.

4. Granowitz EV, Brown RB. Antibiotic adverse reactions and drug interactions. Crit Care Clin 2008;24:421-42, xi.

5. Aiyegoro O, Okoh A. Use of bioactive plant products in combination with standard antibiotics: Implication in antimicrobial chemotherapy. J Med Plants Res 2009;3:1147-52.

6. Betoni JE, Mantovani RP, Barbosa LN, Di Stasi LC, Fernandes Junior A. Synergism between plant extract and antimicrobial drugs used on Staphylococcus aureus diseases. Mem Inst Oswaldo Cruz 2006;101:387-90.

7. Chen MX, Alexander KS, Baki G. Formulation and evaluation of antibacterial creams and gels containing metal ions for topical application. J Pharm (Cairo) 2016;2016:5754349.

8. Rubaka C, Ndakidemi P, Malebo HM, Shahada F. Individual and combined antibacterial activity of crude extracts from medicinal plants Carissa spinarum Linn and Carica papaya Linn. Eurc J Med Plants 2014;4:1513-23

9. Datar PA. Formulation and evaluation of the polyherbal gel prepared using carbopol 934 for threating skin diseases in comparison with ointment using emulsifying ointment. J Pharm Nanotechnol 2013;1:19-21

10. Harahap NI. Antibacterial Activity of Ethanol Extract gel of Sambungrambat leaves (Mikania micrantha Kunth) and Angiogenesis of Infected Excision Wound Healing in Guinea pig. Thesis, Faculty of Pharmacy University of Sumatera Utara; 2017. p. 1-102.

11. Balsam MS, Gerson SD, Reiger MM, Sagarin E. Cosmetic Science and Technology. USA: Wiley-Interscience; 1972

12. Barel AO, Paye M, Maibach HI. Cosmetic Science and Techonolgy. $4^{\text {th }}$ ed. New York: John Willy and Son Inc; 2014.

13. CABI (Centre for Agriculture and Bioscience International). Mikania micranthia. UK: CABI; 2017.

14. Depkes RI. Materia Medika. $6^{\text {th }}$ ed. Jakarta: Ditjen POM; 1995. p. 297-307.

15. Farnsworth NR. Biologycal and phytochemical screening of plants. J Pharm Sci 1996;55:225-76.

16. Harbone JB. Metode Fitokimia: Penuntun Cara Modern Menganalisis Tumbuhan. Vol. 2. Bandung: ITB; 1987. p. 6, 49.

17. Barus BR. Antibacterial Activities Ethanol Extract and Fraction Leaf Morbesi-Besi (Tarenna polycarpa (Miq.) Koord. Ex Valenton) to Some Bacteria. Thesis. Faculty of Pharmacy, University of Sumatera Utara; 2017. p. 1-105.

18. Rajalakshmi K, Banu N. Antimicrobial activity of natural chlorophyllin from endangered medicinal plant Mimosa pudica L. Int J Pharm Pharm Sci 2016;8:387-9.

19. Robinson T. The Organic Constituent of High Plant. $4^{\text {th }}$ ed. New York: University of Massachusetts; 1995.

20. Amoussa AM, Lagnika L, Sanni A. Acacia ataxacantha (Bark): Chemical composition and antibacterial activity of the extracts. Int $J$ Pharm Pharm Sci 2014;6:138-41.

21. Pratiwi ST. Mikrobiologi Farmasi. Jakarta: Erlangga; 2008. 